\title{
Vaikuttava tutkimus Venäjän Karjalan suomenkielisestä kirjallisuudesta
}

\author{
Tuulikki Kurki. 2018. Rajan kirjailijat: Venäjän Karjalan suomenkieliset kirjailijat \\ tilan ja identiteetin kirjoittajina. Helsinki: Suomalaisen Kirjallisuuden Seura. \\ 436 sivua.
}

Ulla Savolainen

$\mathrm{T}$

uulikki Kurjen teos Rajan Kirjailijat: Venäjän Karjalan suomenkieliset kirjailijat tilan ja identiteetin kirjoittajina (2018) on vaikuttava tutkimus suomenkielisestä kirjallisuudesta ja sen rakentumisestä Neuvostoliiton ja Venäjän Karjalassa 1940-luvulta nykypäivään. Kurjen teos analysoi ja esittelee oivaltavasti verrattain vähän suomessa tutkittua ja tunnettua Venäjän Karjalan suomenkielistä kirjallisuutta, joka on tuotettu Neuvostoliiton ideologisissa puitteissa ja poliittisessa kontrollissa. Tämän lisäksi se avaa tuoreita näkökulmia valtioiden ja alueiden rajaseutuihin tiivistyviin ilmiöihin ja merkityksiin, jotka ovat yhtäaikaisesti symbolisia, poliittisia ja territoriaalisia.

Tutkimus noudattaa ajallista kronologiaa niin, että se alkaa esittelemällä suomenkielisen kirjallisuuden muodostumisen puitteet 1920- ja 1930-lukujen Neu-

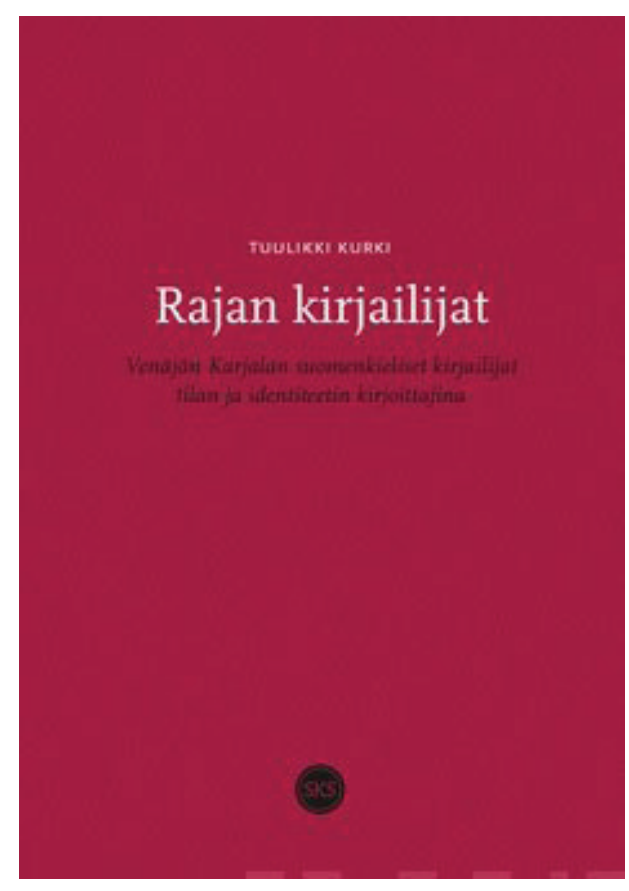
vostoliitossa. Ensimmäinen varsinainen analyysiluku keskittyy toisen maailmansodan jälkeiseen, Stalinin myöhäisen valtakauden tiukasti säädellyn kirjallisuuden aikaan. Toinen luvuista keskittyy Hruštšovin vaihtelevasti sallivamman ja taas kontrolloidumman kauden kirjallisuuteen, jolloin muun muassa paikallisvärin käsite antoi tilaa ei-venäjänkielisen ja etnokansallisen tilan rakentamiseen. Kolmas analyysiluku käsittelee Brežnevin ajan kirjallisuutta, jossa esiin nousevat yhtäältä keskenään ristiriitaiset ideologiset neuvottelut tilasta ja toisaalta uudenlainen tendenssi muotoilla ei-venäjänkielinen tila nimenomaan karjalaiseksi tilaksi. Viimeinen analyysiluvuista keskittyy perestroikan ja Neuvostoliiton hajoamisen jälkeisen ajan kirjallisuuteen, jolle leimallista on irtautuminen sosialistisesta realismista sekä keskittyminen yksilön vaikeisiinkin kokemuksiin sekä karjalaisen tilan kuvaamiseen pirstaleisena, ristiriitaisena ja ylirajaisena. 
Tutkimuksen metodologisen viitekehyksen pohjana ovat kirjallisuuden narratiivien, kuvastojen ja koodien tutkimuksen teoriat sekä monitieteisen rajatutkimuksen näkökulmat, joiden kulttuurintutkimuksellista kulmaa teos pyrkii monipuolistamaan. Tutkimusta varten Kurki on lukenut noin sata suomenkielellä julkaistua kaunokirjallista proosateosta, joista on analysoitu yksityiskohtaisemmin 17 teosta Nikolai Jaakkolalta (1905-1967), Antti Timoselta (1915-1990), Taisto Huuskoselta (1920-1990) ja Arvi Pertulta (1961-). Kaunokirjallisuuden lisäksi tutkimusaineistona on Venäjän Karjalassa vuosina 1947-2014 julkaistuja sanoma-, kirjallisuus- ja kulttuurilehtiä sekä arkisto- ja haastatteluaineistoja.

\section{Kontekstualisoinnin voima}

Tutkimuksen keskeisiä painopisteitä on kaksi. Ensinnäkin Kurki analysoi Neuvosto-Karjalan suomenkielistä kirjallisuutta suhteessa Moskova-johtoiseen kirjallisuusinstituutioon, joka loi kertomusmallit, koodit ja kuvastot ideologisesti oikeanlaiselle ja Neuvostoliiton yhtenäisyyttä tukevalle kirjallisuudelle. Hallitsevin Neuvostoliiton kirjallisuutta ohjaavista koodeista oli sosialistinen realismi. Toiseksi teos tarkastelee tätä kirjallisuutta suhteessa tilallisuuteen ja rajan monimuotoiseen problematiikkaan, johon liittyy raja valtioiden välisenä erottajana, rajaseutuna, sekä symbolisena rajana.

Teoksessa tarkastellaan sitä, miten Venäjän karjalan suomenkielisessä kirjallisuudessa eri aikoina neuvoteltiin neuvostokirjallisuuden ideologisen kuvaston ja koodin puitteissa ei-venäjänkielisestä tilasta sekä mahdollisuuksista ja keinoista rakentaa ylirajaisia identiteettejä. Kurjen tutkimus osoittaa, että tarkasteluaikana suomenkielisen kirjallisuuden tila Neuvostoliitossa oli aluksi hyvin kapea ja selkeärajaisia ideologisia malleja noudattava, mistä se muuttui osaksi monikansallista neuvostotilaa, säilyen kuitenkin yhä vahvasti kytköksissä neuvostoretoriikkaan. Perestroikan ja Neuvostoliiton kaatumisen myötä suomenkielisen kirjallisuuden tila hajosi moniääniseksi hypertilaksi, jota suomenkielisyyden sijaan luonnehtivat neuvottelut ja kilpailu tilasta ja sen merkitysten omistuksesta karjalaisten, inkeriläisten ja vepsäläisten kesken. Identiteetin esittämisen näkökulmasta tämä muutos näkyy siirtymänä ideologisesti mallin mukaisesta neuvostokansalaisesta kohti territoriaaliseen, kielelliseen ja kulttuuriseen rajaan paikantuvaa - ja sitä reflektoivaa - yksilöllistä subjektia.

Kurjen analyyttinen ote kautta tutkimuksen on kontekstualisoiva. Kirjallisuutta tulkitaan suhteessa kirjoitus- ja julkaisuajankohtien sosiaalisiin, yhteiskunnallisiin, ideologisiin ja poliittisiin olosuhteisiin. Tästä huolimatta teoksessa analysoituja teoksia ei leimata latteasti yksinomaan sosialistisen realismin kontrolloimiksi ja määrittelemiksi esimerkeiksi ideologisesta ja poliittisesta kirjallisuudesta, vaan niitä tulkitaan ja luetaan nimenomaan suhteessa näihin koodeihin. Tämä tulkintatapa on erinomainen. Sen kautta Kurki tuo tutkimuksessaan monisävyisesti esiin Karjalan suomenkielisen kirjallisuuden moninaisuutta ja sisäistä varianssia. Tutkimus onnistuukin osoittamaan, että samaan tapaan kuin mitä tahansa lajikonventioita tai malleja, Venäjän Karjalan kirjailijat - ja lukijat - käyttävät myös poliittisesti ja valtiojohtoisesti kontrolloituja kehyksiä eri tavoilla, monenlaisiin tarkoituksiin ja mitä erinäisten merkitysten ilmaisuun.

\section{Irtautumisia}

Mielestäni monella tapaa kiinnostavin osio Kurjen tutkimuksessa käsittelee Moskova-vetoisesta kirjallisuusinstituutiosta irtautuvaa, ennen ja jälkeen Neuvostoliiton kaatumista 
kirjoitettua kirjallisuutta, erityisesti vuonna 1979 Suomessa julkaistua Taisto Huuskosen Laps' Suomen -teosta sekä Arvi Pertun teoksia Petroskoin symposiumi (2001), Skumbria (2011) ja Kipu (2014). Vaikka Huuskosen ja Pertun teokset ovat keskenään hyvin erilaisia ja eri aikoina tuotettuja, yhdistää niitä välienselvittely neuvostokuvastoon ja -koodiin. Kurki tuo luvussa esiin sen, että irtautuminen neuvostoajan kuvastosta ja koodista ei merkitse katkosta, vaan niiden produktiivista uudelleentulkintaa. Tämän kautta tuotetaan uudenlaisia merkityksiä, ambivalentteja ja yhteen keskukseen kiinnittymättömiä identiteettejä sekä rajaseudun hypertilaa. Samaa menneisyyden uudelleen arvioinnin prosessia ilmentää myös se, että neuvostoaikana kirjoitettuja teoksia on alettu 2000-luvulla tulkita uudelleen ensisijaisesti karjalaisena kirjallisuutena.

Analysoidessaan Karjalan myöhäistä kirjallisuutta, Kurki nostaa esiin myös trauman käsitteen. Sen merkitys ja funktio - se onko kyse ensisijaisesti kuvailevasta vai metodologisesta käsitteestä - jää kuitenkin hieman epäselväksi. Käsitettä käytetään historiallisten mullistusten sekä yksilön kokemusten kuvaamiseen, mutta sitä millä perusteella nimeäminen tapahtuu ja mikä tarkalleen ottaen trauman käsitteen analyyttinen funktio on, olisi voinut avata syvällisemmin. Tutkimuksessa ei myöskään oteta kantaa 1990-luvulta alkaen kirjallisuuden-, holokaustin sekä kulttuurisen muistitutkimuksen piirissä hyvin suosituksi nousseeseen traumateoriaan (esim. Felman ja Laub 1992; Caruth 1996) eikä sen mittavaan kritiikkiin (esim. Radstone 2007; Craps 2013). Tämän yhteyden puuttuminen on yllättävää, sillä Venäjän Karjalan suomenkielinen kirjallisuus olisi epäilemättä tarjonnut aivan uudenlaisia näkökulmia myös traumateoriaan, jota on kritisoitu muun muassa sen euro-amerikkalais- ja holokaustikeskeisyyden sekä elitistisen ja kapean, lähinnä modernistisiin muotoihin keskittyvän kirjallisuus- ja taidekäsityksen vuoksi.

\section{Lopuksi}

Tuulikki Kurjen Rajan kirjailijat on hieno tutkimus Venäjän Karjalan suomenkielisestä kirjallisuudesta sekä rajaseutujen ja niiden kirjallisuuksien merkityksistä yleisemminkin. Tutkimuksen yhteenvetoluvussa Kurki käyttää optisen illuusion vertausta kuvatessaan Neuvostoaikaisen kirjallisuuden merkitysten häilyvyyttä ja moninaisuutta, kun sitä tulkitaan erilaisissa yhteiskunnallisissa, historiallisissa ja poliittisissa tilanteissa. Optisessa illuusiossa kuva on sama, mutta sen tulkinta muuttuu riippuen katsojasta, tilanteesta ja odotuksista. Kurjen tutkimus tuo esiin, että Karjalan suomenkielistä kirjallisuutta on tulkittu niin neuvostokirjallisuutena kuin karjalaisena kirjallisuutena, kun taas sen näkeminen muiden rajakirjallisuuksien ja -kulttuurien kontekstissa asettaa sen uudenlaiseen globaaliin asetelmaan, avaten uudenlaisia tulkintahorisontteja. Selvää on myös se, että kuvan muuttuminen ei pysähdy tähän.

\section{Kirjallisuus}

Caruth, Cathy. 1996. Unclaimed Experience: Trauma, Narrative and History. Baltimore and London: Johns Hopkins University Press.

Craps, Stef. 2013. Postcolonial Witnessing: Trauma Out of Bonds. Basignstoke, Houndmills: Palgrave Macmillan. https://doi.org/10.1057/9781137292117 
Felman, Shoshana and Laub, Dori. 1992. Testimony: Crises of Witnessing in Literature, Psychoanalysis and History. New York and London: Routledge.

Huuskonen, Taisto. 1997. Laps' Suomen. Porvoo: Werner Söderström Osakeyhtiö.

Perttu, Arvi. 2001. Petroskoin symposiumi: Romaani. Petroskoi:Verso.

Perttu, Arvi. 2011. Skumbria: Romaani. Helsinki: Like.

Perttu, Arvi. 2014. Kipu: Romaani. Espoo: Myllylahti.

Radstone, Susannah. 2007. “Trauma Theory: Contexts, Politics, Ethics." Paragraph 30(1): 9-29.

Filosofian tohtori Ulla Savolainen työskentelee Suomen Akatemian tutkijatohtorina Helsingin yliopistossa folkloristiikan oppiaineessa. Memory Unchained -hankkeessaan hän tutkii inkeriläisten kokemuksia käsittelevää kirjallisuutta kulttuurisen muistin näkökulmasta. 